\title{
ANALISIS RANTAI NILAI DAN KEBERLANJUTAN INDUSTRI SAGU (Metroxylon sp) RAKYAT KABUPATEN KEPULAUAN MERANTI
}

\author{
Analysis of Value Chains and Sustainability Industry of Sagu (Metroxylon Sp) of Community in Meranti \\ Islands District \\ Siti Khotijah ${ }^{1}$, Rosnita $^{2}$, dan Novia Dewi ${ }^{3}$ \\ ${ }^{1}$ Mahasiswa Jurusan Magister Agribisnis Fakultas Pertanian Universitas Riau \\ ${ }^{2,3}$ Dosen Jurusan Agribisnis Fakultas Pertanian Universitas Riau \\ Program Studi Magister Agribisnis, Fakultas Pertanian, Universitas Riau, Jln. HR. Soebrantas KM 12,5 Panam, \\ Pekanbaru, Indonesia, 28293 \\ E-mail : khotijah0393@gmail.com
}

\begin{abstract}
ABSTRAK
Penelitian ini bertujuan untuk menganalisis (1) rantai nilai produk industri sagu dan (2) tingkat keberlanjutan industri sagu di CV Kilang Sagu Harapan Kepulauan Meranti. Metode penelitian yang digunakan adalah metode survei dan wawancara. Penentuan responden sampel penelitian dilakukan secara purposive sampling yakni pemilik kilang sebagai pelaku usaha, dan sejumlah karyawan kilang yang bertanggung jawab pada setiap proses pengolahan tepung sagu. Analisa data yang digunakan meliputi analisis rantai nilai, margin pemasaran, dan analisis nilai tambah. Hasil penelitian ini menunjukkan pola ,rantai ilia industri sagu yang terlibat adalah petani sebagai pemasok bahan baku. CV KSH sebagai pelaku usaha, dan konsumen akhir. Marjin pemasaran yang diterima pelaku usaha adalah sebesar 76,90 persen atau senilai Rp.3.614/kg dengan efisiensi pemasaran sebesar 48,14 persen atau senilai Rp. 2.262/kg tepung sagu. Hasil analisis nilai tambah menunjukkan bahwa produk tepung sagu memperoleh nilai tambah sebesar Rp. $1.590 / \mathrm{kg}$.
\end{abstract}

Kata kunci : Rantai nilai, industri sagu, nilai tambah

\begin{abstract}
This study aims to analyze (1) the value chain of the sago industry product and (2) the level of sago industry sustainability in CV. Kilang Sagu Harapan, Kepulauan Meranti. This study used survey and interview method. The determination of the research sample respondents was carried out by purposive sampling, namely the owner of the refinery as a business actor, and a number of refinery employees who were responsible for each process of processing sago flour. Analysis of the data used includes value chain analysis, marketing margins, and value added analysis. The results of this study show the pattern, the sago industry chain of ilia involved is farmers as suppliers of raw materials. $\mathrm{CV} \mathrm{KSH}$ as a business actor, and final consumer. The marketing margin received by businesses is 76,90 percent or Rp.3,614/kg with marketing efficiency of 48,14 percent or $R p .2,262 / \mathrm{kg}$ of sago flour. The result of additional value analysis shows that the sago flour product gets additional value of Rp. 1,590/kg.
\end{abstract}

Keywords :Value chain, sago industry, additional value

Diterima : 1 Februari 2020. Disetujui: 24 Agustus 2020 


\section{PENDAHULUAN}

Luas sebaran sagu di Provinsi Riau sekitar 361,146 hektar dan Perkebunan sagu terluas di Provinsi Riau Berada Di Kabupaten Kepulauan Meranti dengan luas 38,614 hektar (BPS 2017). Kepulauan Meranti termasuk salah satu kawasan pengembangan ketahanan pangan nasional karena salah satu sentra penghasil sagu di Indonesia.

Luas areal perkebunan sagu di Kabupaten Kepulauan Meranti 38.614 Ha, dengan Produksi mencapai 200.062 ton per tahun. Perkebunan sagu di Kepulauan Meranti telah menjadi penghasil utama hampir 20 persen masyarakatnya. Ketersediaan sagu yang melimpah diharapkan dapat digunakan sebagai upaya untuk membantu menyelesaikan permasalahan dunia terutama dalam hal pangan dan energi.

Sasaran yang penting dicapai dalam pengembangan sagu diantaranya adalah peningkatan produktivitas sagu, diversifikasi produk dan peningkatan pendapatan petani sagu, dalam mengoptimalkan pemanfaatan sagu dibutuhkan teknologi sagu, antara lain pengolahan tepung sagu, diversifikasi produk dan pemasaran (Deptan, 2008).

Tepung sagu mempunyai kadar gizi, terutama pada protein dan vitamin tetapi merupakan sumber kalori yang sesuai. Sebagai penghasil tepung, peranan sagu untuk mengisi kebutuhan pangan tidak diragukan lagi, bahkan dapat diolah menjadi beberapa jenis makanan yang tersedia di pasar lokal maupun regional.

Pengolahan tepung sagu dapat di lakukan secara tradisional dan modern. Proses produksi tepung sagu secara modern diharapakan dapat memanfaatkan sagu sebagai bahan tepung secara maksimal dan memenuhi kebutuhan pasar. CV Kilang Sagu Harapan merupakan salah satu kilang sagu terbesar sebagai pabrik pengolahan tepung sagu yang berada di Desa Tanjung yang beroperasi secara semi mekanis.

Tujuan umum setiap perusahaan adalah untuk memperoleh laba tertentu, dan hal ini akan dapat tercapai apabila kegiatan penjualan dapat terlaksana sesuai dengan yang direncanakan. Kegiatan penjualan merupakan salah satu dari seluruh kegiatan pemasaran lainnya dimana ditentukan oleh berbagai faktor yang mempengaruhinya,

Upaya perbaikan menuju industri sagu berkelanjutan dengan mempertimbangkan kendala yang ada dengan menggunakan kajian melalui berbagai pendekatan analisis antara lain analisis rantai nilai. Melalui analisis rantai nilai diharapkan dapat melihat serangkaian aktivitas yang dilakukan oleh pelaku usaha untuk menghasilkan sebuah produk hingga sampai ke konsumen. Selain itu, untuk melihat keberlanjutan industri sagu dilakukan analisis nilai tambah, serta perhitungan terkait pemasaran tepung sagu pada CV Kilang Sagu Harapan.

Penelitian ini bertujuan adalah untuk menentukan strategi kompetitif yang berkelanjutan bagi industri sagu rakyat, dapat diuraikan antara lain (1) Menganalisis rantai nilai produk industri sagu di CV Kilang Sagu Harapan, dan (2) Menganalisis tingkat keberlanjutan industri sagu pada CV Kilang Sagu Harapan.

\section{KERANGKA PENELITIAN}

Analisis rantai nilai diperlukan untuk dapat memetakan karakteristik tiap aktor yang terlibat, serta hubungan antar aktor dalam rantai nilai. hal lain termasuk studi aliran produk melalui pola pemasaran. Penelitian ini juga bertujuan untuk mengidentifikasi distribusi rantai nilai industri sagu dengan memahami margin pemasaran dan nilai tambah yang diperoleh setiap aktor yang terlibat pada rantai nilai. 
Dalam perkembangannya seiring dengan menjaga keberlanjutan industri sagu, dan melihat permasalahan yang telah dijuraikan sebelumnya memerlukan kajian mendalam untuk mencari upaya perbaikan menuju industri sagu berkelanjutan. Pendekatan alasisis yang sesuai dengan kerangka fikir penulis antara lain adalah mengumpulkan data melalui survey dan wawancara serta dokumen pendukung. Data yang diperoleh kemudian dilakukan pemetaan rantai nilai untuk mengetahui aktivitas utama dan pendukung dalam industri sagu. Selain itu, analisis nilai tambah dan margin pemasaran tepung sagu juga dilakukan untuk mengetahui nilai-nilai terkait dengan produk.

\section{METODE PENELITIAN}

\section{Tempat dan Waktu Penelitian}

Penelitian ini dilakukan di Desa Tanjung Kecamatan Tebing Tinggi Barat Kabupaten Kepulauan Meranti yang merupakan sentra pengusahaan komoditi sagu dan lokasi CV Kilang Sagu Harapan sebagai tempat penelitian. Pemilihan lokasi penelitian ini berdasarkan pertimbangan lain bahwa Kecamatan Tebing Tinggi Barat merupakan kecamatan yang termasuk daerah dengan areal sagu yang luas dan produksi dagu yang cukup tinggi dibandingkan dengan kecamatan lain. Penelitian ini telah dilakukan dalam kurun waktu 8 bulan yang meliputi proses pra survey, penyusunan proposal, pengumpulan data, pengolahan, dan penulisan hasil penelitian.

\section{Jenis Dan Sumber Data}

Metode Pengumpulan data dengan observasi dan pendekatan kualitatif berkontribusi pada penelitian dengan pengaturan secara alami sehingga mampu menjelaskan proses interaksi sosial dan fenomena yang terjadi (Jackson et al., 2016).

Proses wawancara dilakukan terhadap responden dari aktor lrantai nilai yang terkait dan ditemui secara langsung di lokasi responden bekerja. Dokumen pendukung diperlukan untuk mengumpulkan informasi terkait kebutuhan dalam penelitian.

\section{Populasi Dan Teknik Pengambilan Sampel}

Populasi sampel pada penelitian ini adalah seluruh karyawan yang bekerja di CV Kilang Sagu Harapan. Hal ini dikarenakan metode penelitian ini merupakan studi kasus pada CV Kilang Sagu Harapan. Pemilihan responden pada penelitian ini dilakukan secara sengaja (purposive sampling), yaitu stakeholder yang berkaitan dengan industri sagu antara lain pemilik kilang, serta karyawan yang bertugas mulai dari pelaksanaan kegiatan rantai nilai hulu (bahan baku) sampai hilir (pemasaran) pada industri sagu CV Kilang Sagu Harapan. Penentuan responden berdasarkan kepakaran dan perannya dalam pengambilan kebijakan yang berkaitan dengan industri sagu di CV Kilang Sagu Harapan Kabupaten Kepulauan Meranti.

\section{Teknik Pengumpulan dan Analisis Data}

Pengumpulan data dilakukan dengan wawancara secara mendalam terhadap pelaku usaha terpilih dan stakeholder sesuai dengan peran mereka yang teridentifikasi dalam rantai nilai industri sagu di CV Kilang Sagu Harapan Kepulauan Meranti. Data primer yang dikumpulkan dikumpulkan meliputi pemetaan rantai nilai, antara lain: (1) Pelaku dalam rantai nilai, (2) Aktivitas dalam rantai nilai, dan (3) Nilai rantai atau marjin keuntungan.

\section{Teknik Analisis Data}

\section{Analisis Rantai Nilai}

Analisis rantai nilai dilakukan dengan mengidentifikasi dan mendeskripsikan secara rinci aktivitas-aktivitas yang dilakukan oleh setiap aktor dalam rantai nilai. Kemudian setiap aktivitas yang dilakukan oleh setiap aktor akan dikaitkan dengan biaya. Aktivitasaktivitas yang dilakukan dalam rantai nilai pengolahan tepung sagu ini terdiri dari 
berbagai macam aktivitas yang akan dijelaskan secara deskriptif dan terperinci sesuai dengan keadaan nyata di lapangan.

\section{Margin dan Efisiensi Pemasaran}

Untuk mengetahui nilai margin pemasaran pada setiap aktor yang terlibat maka dilakukan perhitungan dengan menggunakan rumus margin pemasaran (Limbong dan Sitorus, 1987) berikut ini.

$\mathrm{Mp}=\mathrm{Psi}-\mathrm{Pbi}$

Dimana :

$\mathrm{M}=$ Margin pemasaran di tingkat ke-i $(\mathrm{Rp} / \mathrm{Kg})$

Psi = Harga jual di tingkat ke-i $(\mathrm{Rp} / \mathrm{Kg})$

$\mathrm{Pbi} \quad=$ Harga beli di tingkat ke-i $(\mathrm{Rp} / \mathrm{Kg})$

Kemudian untuk menghitung efisiensi pemasaran tepung sagu di CV Kilang Sagu Harapan dihitung dengan menggunakan rumus Soekartawi (2002) sebagai berikut.

Ep $\quad=$ BP/TNP $\times 100 \%$

Dimana :

$\mathrm{Ep} \quad=$ Efisiensi pemasaran $(\%)$
$\mathrm{Bp} \quad=$ Biaya pemasaran $(\mathrm{Rp} / \mathrm{Kg})$

TNP = Total Nilai Produk $(\mathrm{Rp})$

Jika nilai Ep $\leq 50$ persen, maka saluran pemasaran dikatakan efisien dan apabila nila Ep > 50 persen maka saluran pemasaran dikatakan tidak efisien. Semakin besar nilai efisiensi maka semakin tidak efisien pemasaran yang terjadi. Pemasaran akan semakin efisien apabila nilai efisiensi pemasaran (Ep) semakin kecil (Soekartawi, 2002).

\section{Analisis Nilai Tambah}

Analisis nilai tambah dapat dilihat dari perhitungan rugi laba. Laporan rugi laba menurut Djahidin (1983) merupakan laporan tentang keuangan yang berasal dari kegiatan operasi keuangan. Hasil kegiatan diukur operasi keuangan diukur dari selisih antara penjualan yang diperoleh perusahaan dengan biaya yang dikeluarkan. Berikut ini adalah tabel laporan rugi laba yang digunakan untuk mengetahui dan menghitung nilai tambah dari pengolahan tepung sagu $\mathrm{CV} \mathrm{KSH}$.

Tabel 1. Laporan rugi laba

\begin{tabular}{|c|c|c|}
\hline No & Variabel (Output, Input, Harga) & Notasi \\
\hline 1 & Hasil/ produksi (kg/proses) & $\mathrm{a}$ \\
\hline 2 & Bahan baku (kg/proses) & $\mathrm{b}$ \\
\hline 3 & Tenaga kerja (orang/proses) & $\mathrm{c}$ \\
\hline 4 & Faktor konversi $(1 / 2)$ & $d=a / b$ \\
\hline 5 & Koefisien tenaga kerja (3/2) & $\mathrm{e}=\mathrm{c} / \mathrm{b}$ \\
\hline 6 & Harga produk rata-rata $(\mathrm{Rp} / \mathrm{kg})$ & $\mathrm{F}$ \\
\hline 7 & Upah rata-rata (Rp/orang) 1 x produksi & $\mathrm{G}$ \\
\hline \multicolumn{3}{|c|}{ Pendapatan dan Keuntungan } \\
\hline 8 & Harga bahan baku (Rp/kg) & $\mathrm{H}$ \\
\hline 9 & Sumbangan input lain $(\mathrm{Rp} / \mathrm{kg})^{*}$ & I \\
\hline 10 & Nilai produk $(\mathrm{Rp} / \mathrm{kg})(4 \times 6)$ & $\mathrm{j}=\mathrm{d} \times \mathrm{f}$ \\
\hline \multirow[t]{2}{*}{11} & a. Nilai tambah $(\mathrm{Rp} / \mathrm{kg})(10-8-9)$ & $\mathrm{k}=\mathrm{j}-\mathrm{h}-\mathrm{i}$ \\
\hline & b. Ratio nilai tambah $(\%)(11 \mathrm{a} / 10)$ & $1(\%)=\mathrm{k} / \mathrm{j} \times 100 \%$ \\
\hline \multirow[t]{2}{*}{12} & a. Imbalan tenaga kerja (Rp/hk) $(5 \times 7)$ & $\mathrm{m}=\mathrm{e} \times \mathrm{g}$ \\
\hline & b. Bagian tenaga kerja (\%) (12a/11a) & $\mathrm{n}(\%)=\mathrm{m} / \mathrm{kx} 100 \%$ \\
\hline \multirow[t]{2}{*}{13} & a. Keuntungan $(\mathrm{Rp})(11 \mathrm{a}-12 \mathrm{a}) * *$ & $\mathrm{o}=\mathrm{k}-\mathrm{m}$ \\
\hline & b. Tingkat keuntungan $(\%)(13 \mathrm{a} / 11 \mathrm{a})$ & $\mathrm{p}(\%)=\mathrm{o} / \mathrm{kx} 100 \%$ \\
\hline \multirow[t]{4}{*}{14} & Margin $(10-8)(\mathrm{Rp})$ & $q=j-h$ \\
\hline & a. Pendapatan tenaga kerja $(\%) \quad(12 \mathrm{a} / 14)$ & $\mathrm{r}(\%)=(\mathrm{m} / \mathrm{q}) \times 100 \%$ \\
\hline & b. Sumbangan input lain $(\%)(9 / 14)$ & $\mathrm{s}(\%)=(\mathrm{i} / \mathrm{q}) \times 100 \%$ \\
\hline & c. Keuntungan perusahaan $(\%)$ & $\mathrm{t}(\%)=(\mathrm{o} / \mathrm{q}) \times 100 \%$ \\
\hline
\end{tabular}

Sumber: Hayami (1989) 
Analisis nilai tambah menurut Hayami

(1989) sebagai berikut:

\section{Faktor Konversi}

$=$ Hasil produksi dari sekali proses produksi

Jumlah bahan baku sekali proses produksi

Nilai produk

$=$ Faktor Konversi x Harga proses

Koefisien Tenaga Kerja

$=\underline{\text { Jumlah tenaga kerja sekali proses produksi }}$

Jumlah bahan baku sekali proses produksi

Nilai tambah

$=$ Nilai produk - Harga Bahan Baku Sumbangan Input Lain*

Ratio Nilai tambah (\%)

$=\underline{\text { Nilai tambah }} \times 100 \%$

Nilai produk

Imbalan tenaga kerja

$=$ Koefisien tenaga kerja $\mathrm{x}$ upah rata-rata

Bagian tenaga kerja (\%)

$=\underline{\text { Imbalan tenaga kerja }} \times 100 \%$

Nilai tambah

Keuntungan**

$=$ Nilai tambah - Imbalan tenaga kerja

$=\underline{\text { Keuntungan }} \times 100 \%$

Tingkat Keuntungan (\%)

Nilai tambah

Keterangan:

$*$ = Bahan penolong

** = Imbalan bagi modal dan manajemen

\section{HASIL DAN PEMBAHASAN}

\section{Profil Daerah Penelitian}

Kabupaten Kepulauan Meranti memilliki 3 pulau terpisah dengan total 9 kecamatan, 3 diantaranya terletak di pulau tebing tinggi, 3 kecamatan di pulau rangsang, dan 3 kecamatan lainnya teletak di pulau padang.
Luas daratan di Kepulauan Meranti adalah $3.714,19 \mathrm{~km}^{2}$ dan daerah daratan terluas berada di Kecamatan Tebing Tinggi Timur. . Kecamatan Tebing Tinggi Barat sendiri sebagai tempat dilaksanakan penelitian ini memiliki presentase tertinggi kedua sebesar $16 \%$ dengan luas daerah $587,33 \mathrm{Km}^{2}$.

Desa Tanjung merupakan salah satu desa dari 14 desa yang terdapat di Kecamatan Tebing Tinggi Barat dengan luas wilayah 60,00 $\mathrm{Km}^{2}$ dan jumlah penduduk sebanyak 1.223 jiwa terdiri dari 687 jiwa laki- laki serta 536 jiwa perempuan. Berdasarkan data dalam Kepulauan Meranti dalam angka tahun 2017, luas areal perkebunan sagu di Desa Tanjung sebagai lokasi penelitian ini mencapai luas $4.723 \mathrm{Ha}$ dan memiliki produksi mencapai 32.393 Ton/Tahun. Hal tersebut menunjukkan bahwa sagu yang tumbuh dan di tanam pada lahan yang potensial akan menghasilkan produksi yang tinggi.

\section{Profil Perusahaan (CV Kilang Sagu Harapan)}

Pengolahan sagu skala industri sudah lama berkembang di Kabupaten Kepulauan Meranti terutama di Desa tanjung dengan produk utama adalah tepung sagu yang merupakan produk setengah jadi (intermediate product). CV Kilang Sagu Harapan merupakan salah satu kilang sagu terbesar yang berada di Desa Tanjung Kecamatan Tebing Tinggi Barat.

$\mathrm{CV} \mathrm{KSH}$ ini mulai beroperasi pada tahun 1995 pertama kali dioperasikan oleh orangtua dari Bapak Amirudin yang kini meneruskan usaha keluarga tersebut. $\mathrm{CV} \mathrm{KSH}$ memiliki kebun dengan luas $\pm 300 \mathrm{Ha}$ dengan produktivitas per proses produksi (dua hari) mencapai 8,200 kg. Kebutuhan tual sagu untuk di produksi pada pabrik pengolahan ini berkisar mulai dari 400 hingga 450 tual per proses produksi. 


\section{Rantai Nilai Industri Sagu CV KSH}

\section{Aktivitas Utama}

\section{Logisktik Masuk (Inbound)}

Bahan baku yang digunakan dalam pengolahan tepung sagu pada CV. Kilang

Sagu Harapan ini $40 \%$ di peroleh dari hasil kebun yang dimiliki, dan $60 \%$ di peroleh dari petani sagu yang ada di sekitar pabrik. Harga beli bahan baku dari petani rata-rata adalah sekitar Rp. 35.000 - Rp. 40.000.

\section{Operasi}

Pengolahan pada CV. Kilang Sagu Harapan ini menggunakan proses semi mekanis, mesin yang digunakan berjumlah 5 unit yang terdiri dari 1 mesin parut, 1 mesin tarik air, 1 mesin pengaduk dan 2 mesin oven kering. Jam kerja pada mesin perhari sampai dengan 8 jam. Perawatan mesin dilakukan rutin yakni 3 bulan sekali.

\section{Logistik Keluar}

Jadwal pengiriman tepung sagu CV KSH adalah berdasarkan kelancaran pemasaran, maksimal 2 kali dalam satu minggu. CV KSH memiliki gudang penyimpanan tepung sagu sebelum dipasarkan dengan kapasitas penyimpanan 200 ton.

\section{Pemasaran/Penjualan}

CV KSH biasanya menjual tepung sagu dengan kapasitas pengiriman maksimal 52 ton/bulan yang terbagi dalam 5 kali pengiriman ke pasar Cirebon. Pelaku usaha bertanggung jawab terhadap seluruh biaya dalam penjualan tepung sagu ke pasar Cirebon.

\section{Aktivitas Pendukung}

\section{Pengadaan}

Pengadaan bahan baku pada CV KSH sebagai pabrik pengolahan tepung sagu ini dilakukan hampir setiap hari. Harga tual sagu yang dibeli dari petani berkisar antara Rp.35.000 - Rp.40.000 per tual. Harga tual tergantung pada kondisi tual, serta jarak lokasi panen tual sagu sampai ke pabrik pengolahan.

\section{Pengembangan Teknologi}

Terdapat 3 peralatan proses mekanis yang ada di CV KSH, yakni 1 mesin parut tual, 2 oven kering. Frekuensi penggunaan 6 hari per minggu, dengan perawatan mesin rutin pada 3 bulan sekali.

\section{Manajemen Sumber Daya Manusia}

Pengolahan tepung sagu pada CV KSH ini dikerjakan langsung oleh tenaga kerja berjumlah 27 TK yang terbagi dalam 7 jenis pekerjaan antara lain mandor, panen sagu, kupas kulit luar tual sagu, pemarut sagu, pencucian pati sagu,oven kering pati sagu, dan pengemasan tepung sagu.

\section{Infrastruktur perusahaan}

Kegiatan manajemen pada CV KSH dilakukan langsung oleh pelaku usaha seperti aktivitas perencanaan, pengarahan, serta pengendalian dan evaluasi pada pengolahan tepung sagu. sedangkan aktivitas dalam kegiatan produksi diawasi oleh 2 tenaga kerja yang ditentukan langsung oleh pelaku usaha. Selain itu, CV KSH uga telah memiliki berbagai jenis perizinan untuk usaha yang dilakukan.

\section{Pemasaran Tepung Sagu CV KSH}

Pemasaran yang dilakukan pada CV Kilang Sagu Harapan adalah penjualan tetap dalam partai besar ke pasar Cirebon dan tidak menjual kepada pedagang pengumpul maupun pedagang eceran. Pola rantai produksi tepung sagu di mulai dari petani yang menyediakan input bahan baku berupa batang sagu yang telah siap panen.

Aktor kedua pada rantai nilai adalah pelaku usaha yang melakukan proses produksi mulai dari pengolahan batang sagu hingga diperoleh hasil akhir berupa tepung sagu kering yang siap di pasarkan kepada konsumen yang 
merupakan aktor akhir pada pola rantai nilai. marjin pemasaran rantai nilai produksi tepung sagu pada CV Kilang Sagu Harapan untuk harga bahan baku adalah Rp 1.085 per kilogram. Marjin pemasaran yang diterima oleh pelaku usaha adalah sebesar 76,90 persen atau sebesar Rp 3.614 per kilogram dengan efisiensi pemasaran sebesar 48,14 persen atau senilai $\mathrm{Rp}$ 2.262 per kilogram. Nilai efesiensi tersebut menunjukkan bahwa saluran pemasaran $\mathrm{CV}$ $\mathrm{KSH}$ tersebut efisien.

\section{Nilai Tambah Industri Sagu CV KSH}

Perhitungan nilai tambah pada CV Kilang Sagu Harapan menghasilkan nilai marjin dari proses pengolahan tual sagu menjadi tepung sagu adalah sebesar Rp. $1.590 / \mathrm{Kg}$. sedangkan nilai marjin untuk keuntungan perusahaan adalah sebesar Rp. $1.569 / \mathrm{Kg}$ atau sebesar 93,37 persen.

\section{KESIMPULAN DAN SARAN}

Bedasarkan hasil yang telah diuraikan serta mengacu pada tujuan penelitian yang telah ditetapkan sebelumnya, maka diperoleh kesimpulan bahwa:

(1) Pola rantai nilai yang terdapat di CV Kilang sagu harapan adalah di mulai dari petani yang menyediakan input bahan baku. Aktor kedua pada rantai nilai adalah pelaku usaha yang melakukan proses produksi hingga siap di pasarkan kepada konsumen yang merupakan aktor akhir pada pola rantai nilai.

(2) Perhitungan nilai tambah pada CV Kilang Sagu Harapan menghasilkan nilai marjin dari proses pengolahan tual sagu menjadi tepung sagu adalah sebesar Rp. 1.590/Kg. Efisiensi pemasaran sebesar 48,14 persen dan menunjukkan saluran pemasaran CV KSH tersebut efisien.

Penulis memberikan saran yang diharapkan dapat membantu, antara lain adalah (1) Pentingnya memiliki pembukuan yang jelas agar dapat lebih membantu dalam memperhatikan efesiensi dan efektivitas biaya pada produksi pengolahan tepung sagu. (2) terkait harga jual tepung sagu, penulis mengharapkan akan adanya peraturan pemerintah yang dapat berperan dalam menentukan harga jual tepung sagu.

\section{DAFTAR PUSTAKA}

Badan Pusat Statistik Kabupaten Kepulauan Meranti. 2017. Kabupaten Kepulauan Meranti Dalam Angka 2017. Selatpanjang

Hayami Y, Kawagoe T, Marooka Y, Siregar M 1987. Agricultural Marketing and Processing In Upland Java. A Perspective From A Sunda Village. CGPRT Centre. Bogor.

Porter, E. M. 1985. Competitive AdvantageCreating and Sustaining Superior Performance, New York: Free Press.

Soekartawi, 2005. Agribisnis Teori dan Aplikasi. PT. Raja Grafindo Persada,Jakarta.

Sudiyono, Ahmad., 2001. Pemasaran Pertanian. Universitas Muhammadiyah Malang.

Nusaibah, N., Suhesti, E., \& Ratnaningsih, A. T. (2018). Produktivitas dan kualitas sagu pada proses pengolahan secara mekanis dan semi mekanis dan semi mekanis di kec. Merbau kab. Kepulauan meranti. Wahana Forestra: Jurnal Kehutanan, 13(2), 156-16

Ade, F. Y. (2013). Isolasi dan Identifikasi Jamur-Jamur Pendegradasi Amilosa pada Empelur Tanaman Sagu (Metroxylon Sagu Rottb.). Edu Research, 2(1), 27-34.

Samadi, S., Wajizah, S., \& Sabda, S. (2015). Peningkatan Kualitas Ampas Tebu Sebagai Pakan Ternak Melalui Fermentasi dengan Penambahan Level 
Tepung Sagu yang Berbeda. Jurnal Agripet, 15(2), 104-111.

Abbas, B., Listyorini, F. H., \& Martanto, E. A. (2011). Karakteristik Jamur Sagu (Volvariella sp.) Endemik Papua. Jurnal Natur Indonesia, 13(2), 168-173 